\title{
Anti-inflammatory effect of the ethanolic extract from Bowdichia virgilioides H.B.K stem bark
}

\author{
WANDER M. BARROS ${ }^{1}$, VIETLA S.N. RAO ${ }^{2}$, REGILANE M. SILVA ${ }^{1}$, \\ JOAQUIM C.S. LIMA ${ }^{1}$ and DOMINGOS T.O. MARTINS ${ }^{1}$ \\ ${ }^{1}$ Departamento de Ciências Básicas em Saúde - FCM, Universidade Federal de Mato Grosso \\ Av. Fernando Correa da Costa, 2367, Boa Esperança, Campus Universitário, 78060-900 Cuiabá, MT, Brasil \\ ${ }^{2}$ Departamento de Fisiologia e Farmacologia, Faculdade de Medicina, Universidade Federal do Ceará \\ Rua Cel. Nunes de Melo, 1127, Porangabussu, 60430-270 Fortaleza, CE, Brasil
}

Manuscript received on April 3, 2009; accepted for publication on December 3, 2009

\begin{abstract}
Bowdichia virgilioides H.B.K stem bark (Fabaceae), locally known as "sucupira-preta", is a reputed folk-remedy to treat some inflammatory disorders. To validate its traditional claim, the ethanolic extract from B. virgilioides was evaluated in several animal models of inflammation and nociception. The extract at oral doses of 100 to $1000 \mathrm{mg} / \mathrm{kg}$ body weight caused a significant inhibition of carrageenan-induced hind paw oedema, suppression of exudate volume and leukocyte immigration in rat pleurisy induced by carrageenan, and reduction of granuloma weights in the model of subcutaneous granulomas promoted by cotton pellets. In addition, the plant extract significantly inhibited the vascular permeability increase induced by intraperitoneal acetic acid. It also showed marked antinociceptive effect in acetic acid-induced writhing test and in the second phase of formalin test in mice. These findings evidence the anti-inflammatory potential of Bowdichia virgilioides bark and supports its traditional use in inflammatory conditions.
\end{abstract}

Key words: Bowdichia virgilioides, Fabaceae, stem bark extract, anti-inflammatory activity.

\section{INTRODUCTION}

Bowdichia virgilioides H.B.K (Fabaceae), popularly known as "sucupira-preta", is a large tree that widely grows in the hilly and forest regions of north, northeastern and central parts of Brazil. Its bark and seeds are extensively employed in folk medicine in the form of infusion for the treatment of diarrhoea, gout, diabetes, bronchitis, hypertermia, inflammatory conditions of uterus, rheumatism, as body tonic and digestion facilitator (Sanguinetti 1989, Berg 1993, Pott and Pott 1994). Brazil, with the greatest biodiversity, has been and will be a potential source for important pharmacological discoveries to serve mankind and native population by providing some information related to these discoveries. Therefore, scientific investigations on $B$. virgilioides are part

Correspondence to: Domingos Tabajara de Oliveira Martins E-mail: taba@terra.com.br of an important strategy linked to the conservation of biodiversity, discovery of new medicines, and the bettering of the life quality of poor rural communities.

Previous studies described the hypoglycemic activity of bark extract in normal as well as diabetic rats (Leôncio et al. 1994), and antimalarial activity in vitro $\left(\mathrm{IC}_{50}=1 \mu \mathrm{g} / \mathrm{mL}\right)$ and in vivo $(51 \%$ at $100 \mathrm{mg} / \mathrm{kg})$. Phytochemical studies carried out on the bark and root materials have revealed the presence of tannins and lupeol (Calle et al. 1983), alkaloids and terpenoids (Torrenegra et al. 1985, Marinho et al. 1994), volatile constituents and flavonoids (Arriaga et al. 1998, Veloso et al. 1999) and dihydrobenzofuran (Melo et al. 2001). There were also reports of a novel alkaloid named bowdichine and two new isoflavonoids from the stem bark of this plant (Barbosa-Filho et al. 2004, Juck et al. 2006). To the best of our knowledge, no scientific reports on the anti- 
inflammatory or analgesic effects of this plant were so far available. Being part of a programme to find new compounds with anti-inflammatory and antinociceptive activities, the stem bark of $B$. virgilioides was extracted with $70 \%$ of ethanol and evaluated in animal models of inflammation.

\section{MATERIALS AND METHODS}

\section{ANIMALS}

Male albino rats (170-250g) and male Swiss mice (25$30 \mathrm{~g}$ ) were used. The animals were kept in propylene cages at $22 \pm 2^{\circ} \mathrm{C}$ in a $12 \mathrm{~h}$ light-dark cycle, with free access to standard pellet chow and water. Groups of eight to ten animals were used for experimentation. The animals were starved for $18 \mathrm{~h}$ before use. The experimental protocols were approved by the Institutional Animal Care and Use Committee in accordance with the international principles.

\section{Plant Material AND EXTRACTION}

Bowdichia virgilioides bark was collected at the municipality of Chapada dos Guimarães, state of Mato Grosso, Brazil, after its identification and authentication by Prof. Germano Guarin Neto of the Department of Botany and Ecology, Federal University of Mato Grosso, Brazil. A voucher specimen (\# 22591) was deposited at the Herbarium of this university. The collection was authorized by the Brazilian Institute of Environment and Renewable Natural Resources. The finely powdered stem bark $(1.8 \mathrm{~kg})$ was macerated in $70 \%$ of ethanol for a period of 7 days. After this period, the macerate was filtered through a filter paper (no $170 \mathrm{~g}$ ), the filtrate was evaporated using a rotary evaporator $\left(45 \pm 1^{\circ} \mathrm{C}\right)$ under reduced pressure $(625 \mathrm{mmHg})$ to get an yield of $16.91 \%$. For the experiments, this ethanol extract of Bowdichia virgilioides (EEBv) was further diluted in distilled water to reach the necessary concentrations. Controls received the same volume of distilled water as the vehicle.

\section{Phytochemical ScReEning}

In order to verify the presence of different chemical classes, EE $B v$ was subjected to standard screening test (Matos 1988). Conventional protocol for detecting the presence of alkaloids, flavonoids, saponins, tannins, xanthones, steroids, antraquinones, triterpenes, etc., was used.

\section{Carrageenan-Induced Paw Oedema}

The method of Winter et al. (1962) was followed. Paw oedema was induced by subplantar injection of $0.1 \mathrm{~mL}$ of lambda carrageenan $(1 \% \mathrm{w} / \mathrm{v}$ in $0.9 \%$ of saline) into the plantar aponeurosis of the left hind paw in male rats 200-220g). An equal volume of vehicle was injected into the contralateral paw. The volume of both hind-paws up to the ankle joint was measured with a plethysmometer (model 7150, Ugo Basile) immediately before (0) and $30,60,120,180$, and $240 \mathrm{~min}$ after carrageenan. The difference in the volumes between the hind-paws was a measure of the oedema $(\mathrm{mL})$. The plant extract $(100,300$ and $1000 \mathrm{mg} / \mathrm{kg}$ ), and the reference drug, indomethacin ( $5 \mathrm{mg} / \mathrm{kg}$, diluted in $2 \%$ sodium bicarbonate), or the vehicle $(10 \mathrm{~mL} / \mathrm{kg}$ of distilled water), were given orally $60 \mathrm{~min}$ before the subplantar injection of phlogestogen.

\section{Vascular Permeability Test}

The method of Whittle (1964) was used to evaluate the effect of $E E B v$ on vascular permeability in adult albino male mice. Briefly, one hour the after oral administration of vehicle, $\mathrm{EE} B v(100,300$ and $1000 \mathrm{mg} / \mathrm{kg})$, and dexamethasone $(0.5 \mathrm{mg} / \mathrm{kg})$ or indomethacin $(5 \mathrm{mg} / \mathrm{kg})$, $0.1 \mathrm{~mL} / 10 \mathrm{~g}$ b.w. of Evans blue $(2 \% \mathrm{w} / \mathrm{v}$, in normal saline) was intravenously injected through the penial venous plexus. After $10 \mathrm{~min}, 0.4 \mathrm{~mL}$ of $0.5 \%(\mathrm{v} / \mathrm{v})$ of acetic acid solutions was injected in the animals by intraperitoneal route. Twenty minutes later, the mice were killed by cervical dislocation and the abdominal cavity was washed with $0.9 \%$ of saline $(6-8 \mathrm{~mL})$. The washings were pooled, and the absorbance of the solution was measured spectrophotometrically at $590 \mathrm{~nm}$. The amount of dye leakage in the supernatant was calculated from the absorbance measurements.

\section{CARrageenan-INduced Pleurisy}

Pleurisy was induced in rats $(200-220 \mathrm{~g})$ by intrapleural injection of $0.1 \mathrm{~mL} / \mathrm{rat}$ of a $2 \% \mathrm{w} / \mathrm{v}$ of lambda carrageenan suspension in normal saline as described by Vinegar et al. (1978). The plant extract (100, 300 and $1000 \mathrm{mg} / \mathrm{kg})$, dexamethasone $(0.5 \mathrm{mg} / \mathrm{kg})$ or vehicle $(10 \mathrm{~mL} / \mathrm{kg})$ were given orally $60 \mathrm{~min}$ before the injec- 
tion of phlogestogen. Six hours later, the rats were killed by excess ether, the thoracic cavity was opened, and the exudate was collected by aspiration. Exudate volume was measured $(\mathrm{mL})$ and the mobilized leukocytes number in the exudate was quantified using an improved Neubauer haemocytometer.

\section{Cotton Pellet-induced Granuloma}

Cotton pellets weighing $50 \mathrm{mg}$ each were sterilized (autoclaved at $120^{\circ} \mathrm{C}$ for one hour) and implanted subcutaneously in rats through a skin incision on their backs, one on each side of the subscapular region (Winter and Porter 1957). Following the implantation, animals were treated orally with the vehicle $(10 \mathrm{~mL} / \mathrm{kg})$, plant extract $(100,300$, and $1000 \mathrm{mg} / \mathrm{kg})$ or dexamethasone $(0.5 \mathrm{mg} / \mathrm{kg})$ once a day on six consecutive days. On day 7 , the animals were sacrificed with excess ether, the granulomas were dissected and their wet and dry weights (at $60^{\circ} \mathrm{C}$ for $24 \mathrm{~h}$ ) were established.

\section{Chemical Nociception Induced By}

ACETIC ACID AND FormaLIN

In the acetic acid test, male mice were treated orally with the vehicle, $\operatorname{EE} B v(100,300$ and $1000 \mathrm{mg} / \mathrm{kg})$ or indomethacin $(5 \mathrm{mg} / \mathrm{kg})$ one hour before the intraperitoneal injection of $0.1 \mathrm{~mL} / 10 \mathrm{~g}$ of $0.6 \% \mathrm{v} / \mathrm{v}$ of acetic acid (Koster et al. 1959). The number of writhings was counted for a $30 \mathrm{~min}$ period. In formalin test, groups of male mice were treated with the vehicle, EEBv $(100,300$ and $1000 \mathrm{mg} / \mathrm{kg})$, indomethacin $(10 \mathrm{mg} / \mathrm{kg})$ or meperidine (Dolantin ${ }^{\circledR}, 25 \mathrm{mg} / \mathrm{kg} \mathrm{s.c}$ ) and, one hour later (meperidine group), nociception was induced by subplantar injection of $25 \mu \mathrm{L}$ of $2.5 \%$ of formalin in normal saline (Hunskaar and Hole 1987) in each animal. The time spent by the animals on licking the injected hind paw was considered as an index of pain and was measured during the first $5 \mathrm{~min}$ (0-5 $\mathrm{min}$, the first phase), and again between 20 and $30 \mathrm{~min}$ (the second phase).

\section{Thermal Nociception In Hot-Plate Test}

The hot-plate test was used as the thermal pain model (Eddy and Leimbach 1953). Vehicle, EEBv (100, 300 and $1000 \mathrm{mg} / \mathrm{kg}$ p.o.) or meperidine ( $25 \mathrm{mg} / \mathrm{kg}$ s.c.) were administered, respectively, 60 and $15 \mathrm{~min}$ before submitting the mice to hot plate $\left(56 \pm 1{ }^{\circ} \mathrm{C}\right)$. The antinociceptive response was evaluated after 15, 30, 60, 120 and $180 \mathrm{~min}$ by measuring the latency period preceding the animal reaction of licking its hind paw or jump. The cut-off time was set at $45 \mathrm{~s}$ to prevent tissue injury.

\section{StATISTICAL EVALUATION}

All parametric values are given as the means \pm s.e.m. and were analysed by one-way ANOVA followed by Student-Newman-Keul's test. A $P$ value less than 0.05 was considered statistically significant.

\section{RESULTS}

\section{Carrageenan-Induced Paw Oedema}

The time-course of paw oedema in rats treated with the vehicle or test drugs is shown in Table I. In vehicletreated control animals, intraplantar injections of carrageenan provoked an oedema response that was more pronounced at the time periods of 180 and $240 \mathrm{~min}$. The plant extract inhibited the rat paw oedema in a doserelated manner. Paw oedema response was found to be significantly less in rats that received 300 and $1000 \mathrm{mg} /$ $\mathrm{kg}$ of plant extract. Indomethacin pretreated group of animals demonstrated greater inhibitions on the paw oedema development. EEBv (300 and $1000 \mathrm{mg} / \mathrm{kg}$ ) inhibited the carragenin-induced inflammation with the highest activity at 120 and $240 \mathrm{~min}$, with $19 \%(\mathrm{p}<0.01)$ and $20 \%(\mathrm{p}<0.01)$ inhibition, and $36 \%(\mathrm{p}<0.001)$ and $36 \%(\mathrm{p}<0.001)$, respectively. Indomethacin $(5 \mathrm{mg} / \mathrm{kg})$ showed $56 \%(\mathrm{p}<0.001)$ and $52 \%(\mathrm{p}<0.01)$ inhibition at the same time point.

\section{Vascular Permeability}

It is well established that the intraperitoneal injection of acetic acid greatly enhances the vascular permeability and permits vascular leakage of Evans blue dye. The amount of extravasated Evans blue dye following the acetic acid injection $(0.4 \mathrm{~mL}$, i.p.) in control mice was found to be $107 \pm 8 \mu \mathrm{g}$. Pretreatment with EEBv caused significant inhibition $(\mathrm{p}<0.01)$ of vascular permeability and, consequently, of the dye leakage by $32 \%, 27 \%$, and $39 \%$ at the respective doses of 100,300 and $1000 \mathrm{mg} / \mathrm{kg}$, when compared to the untreated control. Indomethacin $(5 \mathrm{mg} / \mathrm{kg})$ and dexamethasone $(0.5 \mathrm{mg} / \mathrm{kg})$ treated positive controls demonstrated much greater inhibitions of dye leakage by $49 \%$ and $58 \%$, respectively. 
TABLE I

Effect of ethanolic extract of Bowdichia virgilioides bark (EEBv) on carrageenan-induced hind paw oedema in rats.

\begin{tabular}{c|c|c|c|l|l|l}
\hline \multirow{2}{*}{ Treatment } & \multirow{6}{*}{$\begin{array}{c}\text { Dosage } \\
(\mathrm{mg} / \mathrm{kg})\end{array}$} & \multicolumn{5}{|c}{$\begin{array}{c}\text { Paw oedema }(\mathrm{mL}) \\
\text { (mean } \pm \text { S.E.M.) }\end{array}$} \\
\cline { 3 - 7 } & & 0.5 & 1 & \multicolumn{1}{|c}{ Time (h) } \\
\cline { 3 - 7 } & - & $0.21 \pm 0.05$ & $0.36 \pm 0.04$ & $0.52 \pm 0.05$ & $0.86 \pm 0.03$ & $1.00 \pm 0.02$ \\
Vehicle & 100 & $0.16 \pm 0.03$ & $0.26 \pm 0.03$ & $0.45 \pm 0.03$ & $0.78 \pm 0.02$ & $0.92 \pm 0.02$ \\
B. virgilioides & 300 & $0.22 \pm 0.03$ & $0.30 \pm 0.05$ & $0.36 \pm 0.06$ & $0.70 \pm 0.05^{* *}$ & $0.80 \pm 0.03^{* *}$ \\
& 1000 & $0.24 \pm 0.03$ & $0.33 \pm 0.04$ & $0.37 \pm 0.04 * *$ & $0.55 \pm 0.03^{* * *}$ & $0.64 \pm 0.02^{* * *}$ \\
Indomethacin & 5 & $0.14 \pm 0.03$ & $0.24 \pm 0.04$ & $0.27 \pm 0.04 * *$ & $0.38 \pm 0.04^{* * *}$ & $0.48 \pm 0.04^{* *}$ \\
\hline
\end{tabular}

Values are expressed as the mean \pm S.E.M. of 8 animals. The drugs were administered orally one hour before the subplantar injection of $0.1 \mathrm{~mL}$ of lambda carrageenan ( $1 \% \mathrm{w} / \mathrm{v}$ in $0.9 \%$ of saline). Asterisks indicate significant difference from the corresponding control. ${ }^{* *} \mathrm{p}<0.01 ;{ }^{* *} \mathrm{p}<0.001$ (One-way ANOVA followed by Student Newman-Keul's test).

\section{Carrageenan-Induced Rat Pleurisy}

As shown in Figure 1, the plant extract produced significant $(\mathrm{p}<0.01)$ inhibition on the carrageenan-induced pleuritic exudate volume (39\%) only at a dose of $1000 \mathrm{mg} / \mathrm{kg}$. However, the leukocyte migration was significantly blocked at all the used doses, reaching the maximum level $(55 \%, \mathrm{p}<0.001)$ at $1000 \mathrm{mg} / \mathrm{kg}$. Dexamethasone $(0.5 \mathrm{mg} / \mathrm{kg})$, the reference drug used in this study, produced $70 \%$ and $61 \%$ of inhibitions, respectively, of pleuritic exudate and leukocyte numbers.

\section{Cotton Pellet-Induced Granuloma}

The plant extract as well as the reference drug, dexamethasone, showed significant inhibitions on the wet and dry weights of granulomas (Fig. 2). Compared to dexamethasone, the plant extract demonstrated less pronounced inhibitions on the development of granulomas. The wet and dry weights of granulomas were reduced by $14(\mathrm{p}<0.05)$ and $24 \%,(\mathrm{p}<0.01)$ and $14(\mathrm{p}<0.05)$ and $19 \%(\mathrm{p}<0.01)$, respectively, at doses of 300 and $1000 \mathrm{mg} / \mathrm{kg}$ of EE $B v$ as against $50 \%$ and $50 \%(\mathrm{p}<0.001)$ of inhibition observed in dexamethasone $(0.5 \mathrm{mg} / \mathrm{kg})$ pretreated group. At similar doses, the dry weights of granulomas were reduced by 17 and $24 \%$ in plant extract treated groups as against $56 \%$ of dexamethasone treatment.

\section{Chemical Nociception Induced By}

\section{ACETIC ACID AND FORMALIN}

The effect of EEBv on nociception induced by acetic acid and formalin are shown on Table II and III, respec- tively. The mean number of observed writhes following intraperitoneal injection of $0.6 \%$ of acetic acid in vehicle-treated control mice were $46 \pm 2$, whereas animal groups that received the plant extract at doses of 100,300 and $1000 \mathrm{mg} / \mathrm{kg}$ or the indomethacin $(5 \mathrm{mg} / \mathrm{kg})$ pretreatments had shown a significantly decreased number of writhes $(28,48,70$, and $87 \%$, respectively). In the formalin test, vehicle-treated animals showed the mean licking times (s) of $59 \pm 5$ in the first phase, and 161 \pm 11 in the second phase. Pretreatment with the extract showed no significant effect on the first phase pain response, but significantly inhibited the second phase (inflammatory pain) response by 24,45 , and $50 \%$ at the doses of 100,300 and $1000 \mathrm{mg} / \mathrm{kg}$, respectively. Indomethacin $(10 \mathrm{mg} / \mathrm{kg})$, a known nonsteroidal antiinflammatory agent (NSAID), also produced an inhibition of $69 \%$ only on the second phase. However, meperidine at a dose of $25 \mathrm{mg} / \mathrm{kg}$, s.c. produced inhibitions at both phases (97 and 98\%, respectively).

\section{Thermal Nociception (Hot Plate Test)}

In the hot-plate test, the plant extract $(100,300,1000$ $\mathrm{mg} / \mathrm{kg}$ ) showed no significant analgesia in the tested doses where the synthetic opiod meperidine $(25 \mathrm{mg} / \mathrm{kg}$, s.c.) demonstrated significant antinociception at 60, 90, 120 and 180 min (data not shown).

\section{DISCUSSION}

Results of this study clearly point out to the anti-inflammatory activity of the bark extract from Bowdichia virgilioides in acute inflammatory conditions. It could 


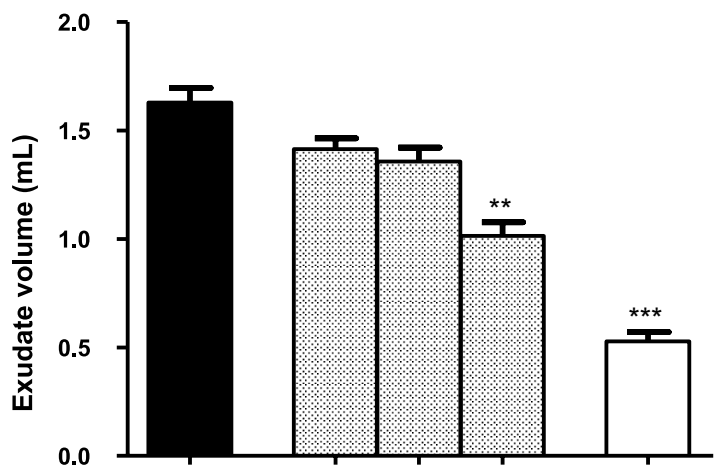

(a)

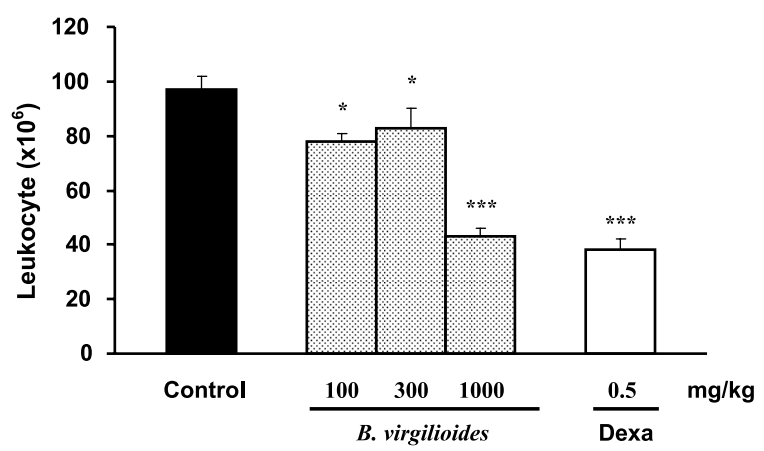

(b)

Fig. 1 - Effect of ethanolic extract of B. virgilioides on exudate volume (a) and leukocyte (b) accumulation in carrageenan-induced pleurisy in rats. Vehicle, Bowdichia virgilioides, 100,300,1000 mg/kg and dexamethasone $0.5 \mathrm{mg} / \mathrm{kg}$. Each column represents the mean \pm S.E.M. of $9-10$ animals. ${ }^{*} \mathrm{p}<0.005 ;{ }^{* *} \mathrm{p}<0.01,{ }^{* * *} \mathrm{p}<0.001$ (One-way ANOVA followed by Student-Newman-Keul's test).

effectively inhibit the acute carrageenan-induced rat hind paw oedema and also the inflammatory exudate and leukocyte migration promoted by carrageenan in rat pleurisy test. In these tests, the effect of plant extract is comparatively less pronounced than that of indomethacin and dexamethasone, the respective reference drugs used in these models that are well known for their inhibitory effects on prostaglandin biosynthesis and leukocyte migration (Ackerman et al. 1980, Miyasaka and Mikami 1982, Wallner et al. 1986). Inflammatory oedema induced by intraplantar injection of carrageenan is believed to result from the action of locally released proinflammatory agents like histamine and serotonin in the initial phase $(1 \mathrm{~h})$, and prostaglandins, the cyclooxygenase products, at a later phase (over $2 \mathrm{~h}$ ). The link between these two phases seems to be provided by

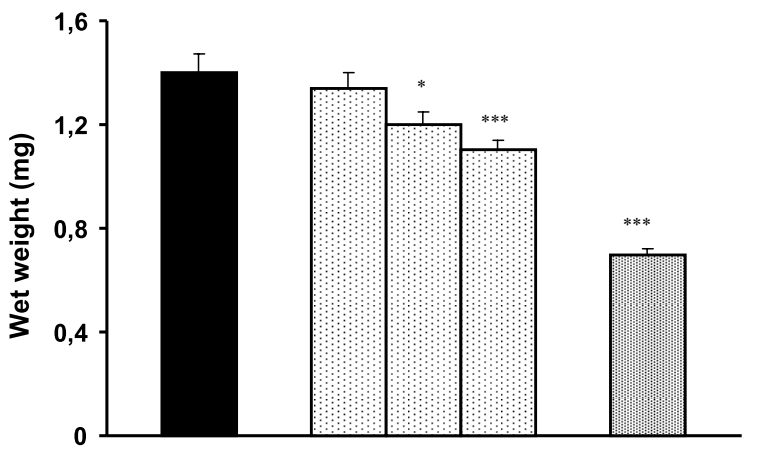

(a)

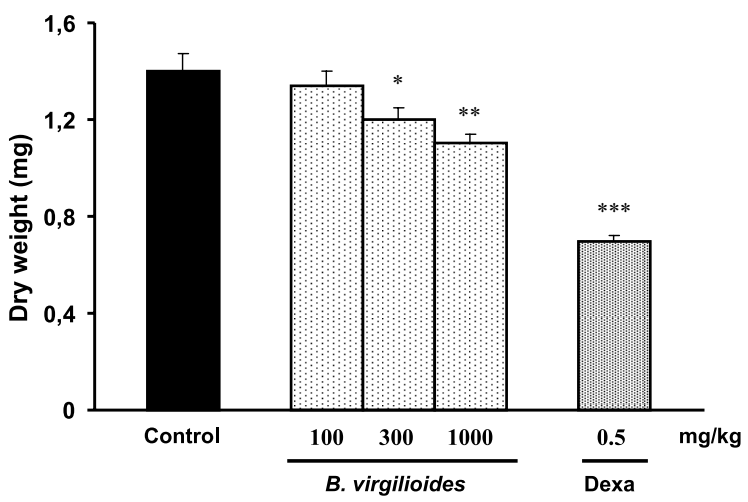

(b)

Fig. 2 - Effects of ethanolic extract of Bowdichia virgilioides on cotton pellets - induced granuloma (a) wet weight and (b) dry weight in rats. Vehicle, B. virgilioides, 100, 300, $1000 \mathrm{mg} / \mathrm{kg}$ and dexamethasone $0.5 \mathrm{mg} / \mathrm{kg}$. Each column represents the mean \pm S.E.M. of 11 animals. ${ }^{*} \mathrm{p}<0.05, * * \mathrm{p}<0.01, * * * \mathrm{p}<0.001$. (One-way ANOVA followed by Student-Newman-Keul's test).

tachykinins that include bradykinin (Winter et al. 1962, Vinegar et al. 1987). More recent studies demonstrated a role for the renin-angiotensin system (RAS) and proinflammatory cytokines in the development of carrageenan-induced paw oedema (Raghavendra and Kulkarni 2000, Lai et al. 2009). All doses of EEBv used in this study showed significant reduction of paw oedema at $2 \mathrm{~h}$ or more after carrageenan injection, suggesting that it produces an anti-oedematous effect during the later phase, similarly to indomethacin, a known cyclooxygenase inhibitor. It implies that $\mathrm{EE} B v$ exerts its antiinflammatory action by either the inhibition of the synthesis, release or the action of mainly the prostaglandins.

Cotton pellet granuloma is a model of non-immunological type of inflammation mediated by the activation of mostly kinins, in particular $\mathrm{B}_{1}$-receptor (Farmer and 
TABLE II

Effect of orally administered ethanolic extract of Bowdichia virgilioides on nociception induced by acetic acid in mice.

\begin{tabular}{c|c|c|c}
\hline Treatment & $\begin{array}{c}\text { Dosage } \\
(\mathrm{mg} / \mathrm{kg})\end{array}$ & $\begin{array}{c}\text { Number of } \\
\text { writhings }\end{array}$ & $\begin{array}{c}\text { Inhibition } \\
(\%)\end{array}$ \\
\hline Vehicle & - & $46 \pm 2$ & - \\
B. virgilioides & 100 & $33 \pm 4 * * *$ & 28 \\
& 300 & $24 \pm 2 * * *$ & 48 \\
& 1000 & $14 \pm 1 * * *$ & 70 \\
Indomethacin & 5 & $6 \pm 1 * * *$ & 87 \\
\hline
\end{tabular}

Values are expressed as the mean \pm S.E.M. of 8 animals. The drugs were administered orally one hour before the intraperitoneal administration of $0.1 \mathrm{~mL} / 10 \mathrm{~g}$ of $0.6 \%$ of acetic acid (writhing test). Asterisks indicate significant difference from the corresponding control. ${ }^{* * *} \mathrm{p}<0.001$ (One-way ANOVA followed by Student Newman-Keul's test).

TABLE III

Effect of orally administered ethanolic extract of Bowdichia virgilioides on nociception induced by formalin in mice.

\begin{tabular}{c|c|c|c}
\hline \multirow{3}{*}{ Treatment } & \multirow{2}{*}{$\begin{array}{c}\text { Dosage } \\
(\mathrm{mg} / \mathrm{kg})\end{array}$} & $\begin{array}{c}\text { Early phase } \\
(0-5 \mathrm{~min})\end{array}$ & $\begin{array}{c}\text { Late phase } \\
(20-25 \mathrm{~min})\end{array}$ \\
\hline Vehicle & - & $59 \pm 5$ & $161 \pm 11$ \\
B. virgilioides & 100 & $46 \pm 3$ & $89 \pm 6^{* * *}$ \\
& 300 & $47 \pm 5$ & $82 \pm 5^{* * *}$ \\
& 1000 & $49 \pm 5$ & $79 \pm 11^{* * *}$ \\
Indomethacin & 5 & $48 \pm 6$ & $50 \pm 6^{* * *}$ \\
Meperidine & 25 & $3 \pm 1^{* * *}$ & $0.4 \pm 0.3^{* * *}$ \\
\hline
\end{tabular}

Values are expressed as the mean \pm S.E.M. of 10 animals. $* * * \mathrm{p}<0.001$

(One-way ANOVA followed by one-way Student Newman-Keul's test).

Burch 1992). In this model, the EEBv demonstrated antioedema as well as antiproliferative effects as evidenced by significant inhibitions of wet and dry weights of granuloma. Thus, it is found to be effective against acute as well as chronic inflammatory conditions, which reflected its efficacy in inhibiting the increase in the number of fibroblasts and synthestising collagen and mucopolysaccharides during the granuloma formation (Recio et al. 1995).

Besides its anti-inflammatory activity, the plant extract demonstrated a significant inhibition on the vascular permeability increase induced by intraperitoneal acetic acid, and an antinociceptive effect in experimental models of acetic acid-induced writhing test and in the second phase of formalin test in mice. Hot-plate test and the first phase nociception in formalin test detect antinociceptive compounds of opioid type that act at the supraspinal sites (Besson and Chaouch 1987). Intraperitoneal injection of acetic acid causes inflammatory pain by inducing capillary permeability (Amico-Roxas et al. 1984) and liberating endogenous substances (histamine, serotonin, prostaglandins and cytokines) that excite pain nerve endings (Raj 1996). The second phase nociceptive response in formalin test seems to depend on the local inflammatory reaction, activation of $N$-methyl-Daspartate (NMDA) and non-NMDA receptors, and the nitric oxide cascade (Davidson and Carlton 1998) and functional changes in the dorsal horn of the spinal cord (Abbott et al. 1995). Thus, the observed antinociceptive effect of $\mathrm{EE} B v$ seems to be a peripheral one since it was found to be inactive in suppressing thermal nociception in the hot-plate test.

Preliminary phytochemical studies carried out on $\mathrm{EE} B v$ demonstrated the presence of triterpenoids, tannins, flavonoids, alkaloids and athraquinones. These different classes of metabolites possess several pharmacological effects that includes an anti-inflammatory activity (Allcarz and Jiménez 1988, Safayhi and Sailer 1997, Buniatian et al. 1998, Kumar et al. 1998 and Ivanovska et al. 1999). Although the exact nature of phytochemical constituent (s) responsible for anti-inflammatory action remains unclear, the data seem to correlate well with the traditional indication of Bowdichia virgilioides in inflammatory conditions. However, further investigations are necessary to explore the mechanism(s) involved in its anti-inflammatory action.

\section{ACKNOWLEDGMENTS}

The authors are grateful to Superintendência do Desenvolvimento da Amazônia (SUDAM), Conselho Nacional de Desenvolvimento Científico e Tecnológico (CNPq) and Coordenação de Aperfeiçoamento de Pessoal de Nível Superior (CAPES) for the financial support.

\section{RESUMO}

A casca do caule de Bowdichia virgilioides H.B.K (Fabaceae), conhecida localmente como sucupira-preta, é um remédio popular muito utilizado para tratar inflamações. Com o objetivo de validar sua crença popular, o extrato etanólico de $B$. virgilioides foi avaliado em vários modelos experimentais de inflamação e 
nocicepção. O extrato administrado, via oral, em doses de 100 a $1000 \mathrm{mg} / \mathrm{kg}$ de peso corporal produziu inibição significativa no edema de pata induzido por carragenina, no aumento na permeabilidade vascular induzido por acido acético, no volume de exudato e na migração leucocitária no teste de pleurisia induzida por carragenina, bem como no peso de granulomas induzidos por pelotas de algodão, em ratos. Em camundongos, o EE $B v$ reduziu o número de contorções abdominais induzidas por ácido acético e a lambedura da pata na segunda fase do teste da formalina. Esses resultados validam o potencial antiinflamatório da casca de Bowdichia virgilioides e referendam seu uso tradicional em condições inflamatórias.

Palavras-chave: Bowdichia virgilioides, Fabaceae, extrato da casca, atividade anti-inflamatória.

\section{REFERENCES}

Abbott FV, Franklin KB and Westbrook RF. 1995. The formalin test: scoring properties of the first and second phase of the pain response in rats. Pain 60: 91-102.

ACKerman N, TOMOLONis A, Mirriam L, KheiferERTS J, Martinez S AND CARTER A. 1980. Three day pleural inflammation: a new model to detect drug effects on macrophage accumulation. Pharmacol Exp Ther 215(3): 588-595.

Allcarz MJ And JimÉnez MJ. 1988. Flavonoids as antiinflammatory agents. Fitoterapia 59: 25-38.

Amico-Roxas M, Caruso A, Trombadore S, Scifo R AND SCAPAGINI U. 1984. Gangliosides antinociceptive effects in rodents. Arch Int Pharmacodyn Ther 272: $103-$ 117.

Arriaga AMC, Machado MIL, Gomes GA AND CRAVEIRO AA. 1998. Volatile constituintes from roots of Bowdichia virgilioides Kunt. J Essent Oil Res 10(2): 205-206.

Barbosa-Filho JM, da Silva Almeida JR, DE OliveiRA Costa VC, DA-Cunha EV, DA Silva MS AND BRAZ-FILHO R. 2004. Bowdichine, a new diaza-adamantane alkaloid from Bowdichia virgilioides. J Asian Nat Prod Res 6: 11-17.

Berg ME. 1993. Plantas medicinais da amazônia: Contribuição ao seu conhecimento sistemático. Belém: Mus Para Emílio Goeldi, 2 ${ }^{\text {nd }}$ ed., 122 p.

Besson JM And ChaOUCH AJ. 1987. Peripheral and spinal mechanisms of nociception. Physiol Rev 67: 67-186.

Buniatian ND, CHIKITKINA VV AND IAKOVLEVA LV. 1998. The hepatoproctive action of ellagotannins. Eksp Klin Farmakol 61: 53-55.
Calle AJ, Rivera Umana A And Moreno E. 1983. Isolation of lupeol from the bark of Bowdichia virgiloides H.B.K. Rev Col Cienc Quim-Farm 4: 93-94.

DAVIDSON EM AND CARLTON SM. 1998. Intraplantar injection of dextrorphan, ketamine or mematine attenuates formalin-induced behaviors. Brain Res 785: 136-142.

EDDY NB AND LEIMBACH D. 1953. Synthetic analgesics II. Dithienylbutenyl and dithienylbutyl-amines. J Pharmacol Exp Ther 107: 385-393.

FARMER SG AND BURCH RM. 1992. Biochemical and molecular pharmacology of kinin receptors. Ann Rev Pharmacol Toxicol 32: 511-532.

HUNSKAAR S AND HoLE K. 1987. The formalin test in mice: dissociation between inflammatory and non-inflammatory pain. Pain 30: 103-114.

IVANOVSKA N, Hristova M AND Philipov S. 1999. Complement modulatory activity of bisbenzylisoquinoline alkaloids isolated from isopyrum thalictroides - II. Influence on c3-9 reactions in vitro and antiinflammatory effect in vivo. Int J Immunopharmacol 21(5): 337-347.

Juck DB, DE REZENDE LC, DAVID JP, DE QueIROZ LP AND DAVID JM. 2006. Two new isoflavonoids from Bowdichia virgilioides. Nat Prod Res 1: 27-30.

Koster R, Anderson M And de Beer EJ. 1959. Acetic acid for analgesic screening. Fed Proceed 18: 412-414.

Kumar A, Dhawan S And Aggarwal BB. 1998. Emodin (3-metil-1,6,8-trihydroxyanthraquinone) inhibits TNF inuded $\mathrm{NF}-\mathrm{Kb}$ activation, IkB degradation, and expressin of cell surface adhesion proteins in humam vascular endothelial cells. Oncogene 17(7): 913-918.

Lai SC, Peng Wh, Huang SC, Ho Yl, Huang TH, LAI ZR AND Chang YS. 2009. Analgesic and antiinflammatory activities of methanol extract from Desmodium triflorum DC in mice. Am J Chin Med 37(3): 573588.

LEÔnCIO MP, SAntos RVH, Anjos FBR, AfIAlpour P AND LIMA CSA. 1994. Estudo do extrato hidroalcoólico da Bowdichia virgiloides Kunth. Sobre a glicemia de ratas diabéticas. Resumo dos anais do XIII Simpósio de Plantas Medicinais, Fortaleza, CE, Brasil.

Marinho LC, Cunha MTMC, Thomas G And BarboSA-FILHO JM. 1994. Constituents of da Bowdichia virgilioides. Fitoterapia 65(5): 475.

MATOS FJA. 1988. Introdução à Fitoquímica Experimental. $1^{\mathrm{a}}$ ed., Fortaleza, Ceará, Imprensa Universitária da UFC, $128 \mathrm{p}$.

Melo FN, Navarro VR, Silva MS, da-Cunha EV, BARBOSA-FILHO JM AND BRAZ-FILHO R. 2001. Bow- 
denol, a new 2,3-dihydrobenzofuran constituent from Bowdichia virgilioides. Nat Prod Lett 15(4): 261-266.

Miyasaka K And Mikami T. 1982. Comparison of the anti-inflammatory effects dexamethasone, indomethacin and BW755C on carrageenin-induced pleurisy in rats. Eur J Pharmacol 77(4): 229-236.

PotT A AND PotT VJ. 1994. Plantas que curam. Embrapa, 161.

RAGHAVENDRA V AND KULKARNI SK. 2000. AT1 receptor antagonism enhances angiotensin-II facilitated carrageenan-induced paw oedema. Clin Pharmacol 22(8): 633638.

RAJ PP. 1996. Pain mechanism. In: RAJ PP (Ed), Pain Medicine: a comprehensive review. St. Louis: Mosby, p. 12-23.

Recio MC, Giner RM, Manez S And Ros JL. 1995. Structural requirements for the anti-inflammatory activity of natural triterpenoids. Planta Med 61: 182-185.

SAFAYHI H AND SAILER ER. 1997. Anti-inflammatory actions of pentacyclic triterpenes. Planta Med 63: 487-493.

SAnguinetTi EE. 1989. Plantas que curam. Rigel (Ed), $2^{\text {nd }}$ ed., $184 \mathrm{p}$.

TORRENEGRA GR, ESCARRIA RS, BAUEREISS P AND ACHENBACH H. 1985. Homoormosanine, the major alkaloid of the bark from Bowdichia virgiloides. Planta Med 3: 276-277.
Veloso SM, Silva BP, Bernardo RB and Parente JP. 1999. Odoratin 7-o-b-D-glucopyranoside from Bowdichia virgilioides. Phytochemistry 52: 1473-1478.

Vinegar R, Truax JF, SElph JL, Lea A AND Johnston PR. 1978. Quantitative in vivo studies of the acute actions of anti-inflammatory drugs in the rat. Eur J Rheum Inflam 1: 204-211.

Vinegar R, Truax JF, Selph JL, Johnston PR, VenABle AL And MacKenZIE KK. 1987. Pathway to carrageenan-induced inflammation in hind limb of the rat. Fed Proceed 46: 118-126.

WALLnER BP ET AL. 1986. Cloning and expression of human lipocortin, a phospholipase A2 inhibitor with potencial anti-inflammatory activity. Nature 320(6057): 77-81.

Whittle BA. 1964. The use of changes in capillary permeability in mice to distinguish between narcotic and nonnarcotic analgesics. Br J Pharmacol 22: 246-253.

WinTER CA AND PORTER CC. 1957. Effect of alterations in side chain upon antiinflammatory and liver glycogen activities of hydrocortisone esters. J Am Pharm Assoc 46: $515-519$.

Winter CA, Risley EA AND Nuss GW. 1962. Carrageenin-induced edma in hind paw of rat as an assay for antiinflammatory drugs. Proc Soc Exp Biol Med 3: 544-547. 